\title{
Znaczenie lokalnych zasobów kulturowych w zagospodarowaniu turystycznym przestrzeni wiejskiej Kotliny Kolskiej
}

\section{The significance of local cultural resources for the development of tourism infrastructure in the Koło Basin rural area}

\section{Marcin GORĄCZKO • Jolanta CICHOWSKA}

Uniwersytet Technologiczno-Przyrodniczy w Bydgoszczy

Wydział Budownictwa, Architektury i Inżynierii Środowiska

ul. Sucha 9, 85-789 Bydgoszcz

gorgon@utp.edu.pl•jolanta.cichowska@utp.edu.pl

Zarys treści: Tworzenie infrastruktury turystycznej na terenach wiejskich Kotliny Kolskiej nie wykroczyło jeszcze poza fazę inicjalną, o czym świadczyć może słabo rozwinięta w regionie baza noclegowa. Jedną z głównych przyczyn takiego stanu jest mała atrakcyjność krajobrazowa obszaru. Szans na aktywizację turystyki wiejskiej należy więc upatrywać raczej w wykorzystaniu potencjału miejscowych zasobów kulturowych, które jak wynika z przeprowadzonej dotychczas waloryzacji kulturowo-turystycznej, są w analizowanym regionie i jego otoczeniu dość znaczne. Kotlina Kolska cechuje się niezbyt korzystnymi warunkami naturalnymi do prowadzenia wielkotowarowej i wielkoobszarowej produkcji rolnej, ale dzięki temu przetrwał tutaj zgodny z oczekiwaniami przeciętnego turysty tradycyjny krajobraz kulturowy polskiej wsi. Przykładem jest dobrze zachowana tradycyjna zabudowa wiejska wznoszona z miejscowego kamienia wapiennego, co jest ewenementem na skalę nizinnej części kraju. A jednak właściciele występujących tu obiektów turystyki wiejskiej w swoich ofertach rzadko nawiązują do specyfiki lokalnych zasobów kulturowych, akcentując atrakcje raczej pospolite, głównie przyrodnicze, którym nadają wyższą rangę niż ma to miejsce w rzeczywistości.

Słowa kluczowe: turystyka wiejska, atrakcyjność turystyczna, potencjał kulturowy, zasoby lokalne, Kotlina Kolska.

\section{Wprowadzenie}

Świadczenie usług turystycznych jest jedną z popularniejszych form pozarolniczej działalności gospodarczej realizowanej na obszarach wiejskich w Polsce (Bański 2004; Bednarek-Szczepańska i Bański 2014). Zjawisko to na terenie kraju cechuje się jednak znacznym zróżnicowaniem pod względem intensywności i dynamiki rozwoju (Bański 2010). Występując powszechnie w typowych regionach turystycznych, podgórskich, pojeziernych i nadmorskich (Bednarek-Szczepańska i Bański 2016; Bański 2016), wpisuje się w ustalony już od dawna kierunek aktywności gospodarczej, zorientowanej na zaspokajanie potrzeb turystów, mimo iż wykracza poza ugruntowane schematy typowo rolniczej aktywności zawodowej. Podobne przedsięwzięcia, ale podejmowane już na obszarach monofunk- 
cyjnych, mają cechy działalności pionierskiej i jako takie obarczone są zdecydowanie większym ryzykiem niepowodzenia. Stąd też w ich przypadku tak ważna jest umiejętność prawidłowej i obiektywnej oceny zasobów lokalnych stanowiących o potencjale turystycznym danego terenu i jego atrakcyjności. W przypadku turystyki wiejskiej szeroko rozumiane atrakcje kulturowe coraz częściej decydują o kierunkach ruchu turystycznego, a przynajmniej w istotnym stopniu, obok zasobów przyrodniczych, współdecydują o nich (Kowalczyk 2002; Kałamucki 2003; Piotrowski i Idziak 2004; Kozak 2006; Kałowska i Poczta-Wajda 2008; Cynarski i Słopecki 2011; Cichowska 2011, Durydiwka 2012; Poczta 2013; Dmochowska-Dudek i in. 2015). Zagadnienie to przedstawiono na przykładzie regionu Kotliny Kolskiej, który zaliczany jest do terenów o niskiej atrakcyjności przyrodniczej (Bartkowski 1986) oraz o najniższych w kraju walorach estetycznych (Bański 2016).

Głównym celem pracy była identyfikacja kulturowych walorów występujących na obszarze Kotliny Kolskiej i w jej bezpośrednim otoczeniu oraz zdiagnozowanie, w jakim zakresie nawiązują do nich i wykorzystują je właściciele wiejskich obiektów turystycznych w swoich ofertach rekreacyjno-wypoczynkowych. Przyjęto, że to wiejska baza noclegowa jako element zagospodarowania turystycznego (Kowalczyk i Derek 2010) zwykle stanowi zalążek do powstawania dalszych, bardziej wyspecjalizowanych przedsięwzięć związanych z obsługą ruchu turystycznego.

\section{Metodyka pracy}

Do osiągnięcia zamierzonego celu wykorzystano różne metody badawcze. W szczególności miały one za zadanie:

- określić granice obszaru objętego rozpoznaniem w ujęciu administracyjno-geograficznym (regionalnym),

- przybliżyć uwarunkowania społeczno-gospodarcze, które mogą wpływać na całościowy potencjał turystyczny analizowanego regionu i decydować o perspektywach jego rozwoju,

- zwaloryzować atrakcyjność turystyczno-kulturową badanego obszaru,

- zdiagnozować potencjał wiejskiej bazy turystycznej i ocenić, czy jej wyróżnikiem jest produkt stworzony w oparciu o elementy dziedzictwa kulturowego,

- określić przewidywane kierunki rozwoju wiejskiej infrastruktury turystycznej w Kotlinie Kolskiej.

W pierwszym przypadku za podstawę wytyczenia granic obszaru badań przyjęto klasyfikację fizycznogeograficzną Polski J. Kondrackiego (1998), w której Kotlina Kolska została wydzielona w randze mezoregionu 318.24. Z kolei uwarunkowania społeczno-gospodarze scharakteryzowano w oparciu o wybrane dane za rok 2015 pochodzące z Bazy Danych Lokalnych GUS (BDL 2016). Przeanalizowano w tym zakresie m.in. strukturę demograficzną mieszkańców Kotliny Kolskiej, strukturę sieci osadniczej, wybrane elementy infrastruktury technicznej, jak również stopę bezrobocia i liczbę podmiotów gospodarki narodowej. Ponadto wykorzystano opracowania kartograficzne pozwalające na określenie kierunków rozwoju gospodarczego na terenach wiejskich badanego regionu na tle kraju (Bański 2010, 2016).

Zagadnienie oceny miejscowych walorów turystycznych, stanowiące istotny element procesu planowania rozwoju turystyki (Duda-Seifert 2015), zostało szeroko roz- 
poznane w literaturze. Dotychczas opracowano szereg metod waloryzacji atrakcyjności turystycznej, a ich przegląd zawarli w swoich publikacjach np. R. Przybyszewska-Gudelis i in. (1979), G. Gołembski (1999), W. Cabaj i Z. Kruczek (2007), M. Nowacki (2007), Z. Kruczek (2011), A. Ziernicka-Wojtaszek i T. Zawora (2011), M. Durydiwka (2012) oraz L. Przezbórska-Skobiej (2014). Już sama liczba prac na ten temat wskazuje na złożoność problemu, jakim jest opracowanie uniwersalnych zasad waloryzacji atrakcyjności turystycznej badanych obszarów (np. jednostek administracyjnych różnego szczebla, regionów fizycznogeograficznych, miejscowości turystycznych itp.) tak bardzo zróżnicowanych pod względem krajobrazowym, gospodarczym i kulturowym, jak to ma miejsce w przypadku Polski.

W niniejszej pracy oceny atrakcyjności turystycznej lokalnych zasobów kulturowych w Kotlinie Kolskiej i jej bezpośrednim otoczeniu dokonano na podstawie wyników dotychczasowych badań potencjału turystyczno-kulturowego prowadzonych w tym rejonie kraju (Główczyńska 2009; Stefańska 2010; Gorączko i Gorączko 2016a, 2016b), zgodnie z metodyką opracowaną przez A. Mikos v. Rohrscheidt (2010). Autor ten opracował zasady bonitacji punktowej walorów turystycznych obejmującej cztery podstawowe kategorie walorów badanego obszaru:

I - „Potencjalne cele turystyki kulturowej"

II - „Elementy obsługi turystycznej”

III - „Oferta czasu wolnego" oraz

IV - „Inne czynniki wpływające na turystykę kulturową”.

Zgodnie z założeniem waloryzacji punktacja poszczególnych czynników przeprowadzona jest najpierw osobno w poszczególnych kategoriach, a następnie zestawiona w ogólnym wyniku. Najistotniejsze znaczenie (z punktu widzenia atrakcyjności regionu dla turystyki kulturowej) ma kategoria pierwsza, natomiast pozostałe mają znaczenie pomocnicze i określają stopień rozwoju infrastruktury służącej turystyce (kategoria II), ogólną atrakcyjność regionu w aspekcie kulturowym i czasu wolnego, bezpośrednio związanymi z turystyką kulturową i turystyką w ogólności (kategoria III) oraz obecność innych dodatkowych czynników wpływających pośrednio na rozwój turystyki kulturowej w regionie (kategoria IV). Punktacja wyznaczona za obiekty z kategorii II, III i IV nie odzwierciedla ich rzeczywistej wartości dla analizowanego obszaru, a jedynie ich ograniczoną rolę i komplementarne znaczenie w tym segmencie turystki. Dlatego faktyczną oceną potencjału turystyczno-kulturowego jest kategoria pierwsza i to liczba punktów w tej kategorii decyduje o zasadniczej klasyfikacji obszaru pod względem potencjału kulturowo-turystycznego (Mikos v. Rohrscheidt 2010). W efekcie w zależności od uzyskanego wyniku bonitacji badany obszar zaliczony może być do jednej z czterech wydzielonych klas: potencjał niski (<100 pkt), potencjał średni (100-250 pkt), potencjał wysoki (250-450 pkt) i potencjał bardzo wysoki (>450 pkt). Zgodnie z założeniami waloryzacji kulturowo-turystycznej A. Mikos v. Rohrscheidt (2010) podlegają jej jednostki podziału terytorialnego II stopnia, a więc powiaty, a w przypadku miast wydzielonych ocena ich potencjału jest przeprowadzana wraz z otaczającym je powiatem ziemskim.

Procedura waloryzacji standardowo obejmuje kwerendę fachowej literatury, inwentaryzację w terenie (w tym wizję lokalną) obiektów historycznych i innych atrakcji turystycznych, placówek kulturalnych, obiektów gastronomicznych i hotelarskich, spotkania z przedstawicielami urzędów administracji samorządowej, personelem informacji turystycznej połączone z tematycznymi wywiadami dotyczących poszczególnych obiektów, 
miejscowości, wydarzeń i turystyki w mikroregionie, w tym jego historii, regularnych eventów kulturalnych oraz założeń strategii rozwoju.

Jakkolwiek opisywana metoda waloryzacji została opracowana w celu określenia atrakcyjności kulturowej danego obszaru, wydaje się, że w rozpatrywanym przez autorów przypadku na ogół w wystarczającym stopniu uwzględnia ona również miejscowe zasoby przyrodnicze. W kategorii I („Potencjalne cele turystyki kulturowej”) punktowany jest fakt instytucjonalnej ochrony przyrody i krajobrazu (parki narodowe, krajobrazowe i rezerwaty), występowania parków kultywowanych, ogrodów przy rezydencjach, ogrodów botanicznych, arboretum, palmiarni i obiektów zoologicznych. W kategorii II („Elementy obsługi turystycznej”) uwzględniane są przystanie rzeczne, co pośrednio informuje o zagospodarowaniu istniejących w obrębie analizowanego terenu zasobów wód płynących. Generalnie jednak atrakcje krajobrazowe (w tym występowanie pomników przyrody, ogólnodostępnych plaż morskich, jeziornych i rzecznych) uwzględniane są w kategorii III („Pozostała oferta czasu wolnego”). Z kolei w kategorii IV („Inne czynniki wpływające na turystykę kulturową") punktowany jest fakt objęcia obszaru ochroną uzdrowiskową.

Warto jeszcze dodać, że na korzyść metody A.Mikos v. Rohrscheidt przemawia skala jej zastosowania. Począwszy od 2008 r. do chwili obecnej została ona wykorzystana do szczegółowej oceny potencjału turystyczno-kulturowego 83 powiatów, w tym wszystkich na terenie województwa wielkopolskiego. Jak przewiduje jej autor, docelowo opracowaniem ma zostać objęty obszar całego kraju.

Potencjał obiektów turystycznych działających na obszarze wsi zdiagnozowano w oparciu o listy adresowe zebrane z urzędów gmin, starostw powiatowych oraz portali turystycznych. Pozostałe istotne informacje potrzebne do oceny każdej prowadzonej usługi uzyskano drogą wywiadu ukrytego (telefonicznego), który, jak można wnioskować z samej jego nazwy, odróżnia się tym od jawnego, że ankieter ukrywa swoją faktyczną rolę, udając, że to co słyszy, specjalnie go nie interesuje. Włączając się do rozmowy i ukierunkowując jej przebieg, czyni to jakby z osobistej (a nie służbowo motywowanej) inicjatywy. Uznano, że zastosowana technika będzie skuteczniejszym sposobem dotarcia do prawdziwych informacji i szerszych wypowiedzi, aniżeli wywiad jawny (Sołoma 2002). W szczególności zagadnienia poruszane podczas wywiadu odnosiły się do określenia profilu prowadzonej przez respondentów usługi turystycznej (wypoczynku u rolnika, wypoczynku na wsi), zagospodarowania turystycznego w elementy służące do odpoczynku i relaksacji oraz oceny, czy prowadzona działalność opiera się na wykorzystaniu elementów kulturowanych Kotliny Kolskiej. Przeprowadzone badanie obejmowało całą interesującą nas zbiorowość, miało zatem charakter wyczerpujący. Każda rozmowa trwała przeciętnie 15-20 minut, a ankieter przyjął postawę turysty zainteresowanego ofertą, chcącego poznać jej warunki i możliwości czynnego wypoczynku.

\section{Określenie granic badanego obszaru}

Kotlina Kolska o powierzchni około 960 km² stanowi charakterystyczne rozszerzenie południkowo przebiegającej w tym miejscu doliny Warty i uchodzącego do niej od wschodu Neru. Region położony jest na północnym skraju podprowincji Nizin Środkowopolskich i graniczy z dziewięcioma mezoregionami fizycznogeograficznymi (Kondracki 1998) reprezentującymi szerokie spektrum typów krajobrazu nizinnego: pojezierzy, wysoczyzn 
morenowych, równin denudacyjnych oraz dolin rzecznych. Etnograficznie Kotlina Kolska znajduje się na granicy ziemi łęczyckiej, wschodniej Wielkopolski i ziemi sieradzkiej, natomiast pod względem administracyjnym położona jest na styku województw łódzkiego i wielkopolskiego, wchodząc w skład pięciu powiatów: kolskiego, tureckiego, poddębickiego, łęczyckiego i pabianickiego (ryc.1).
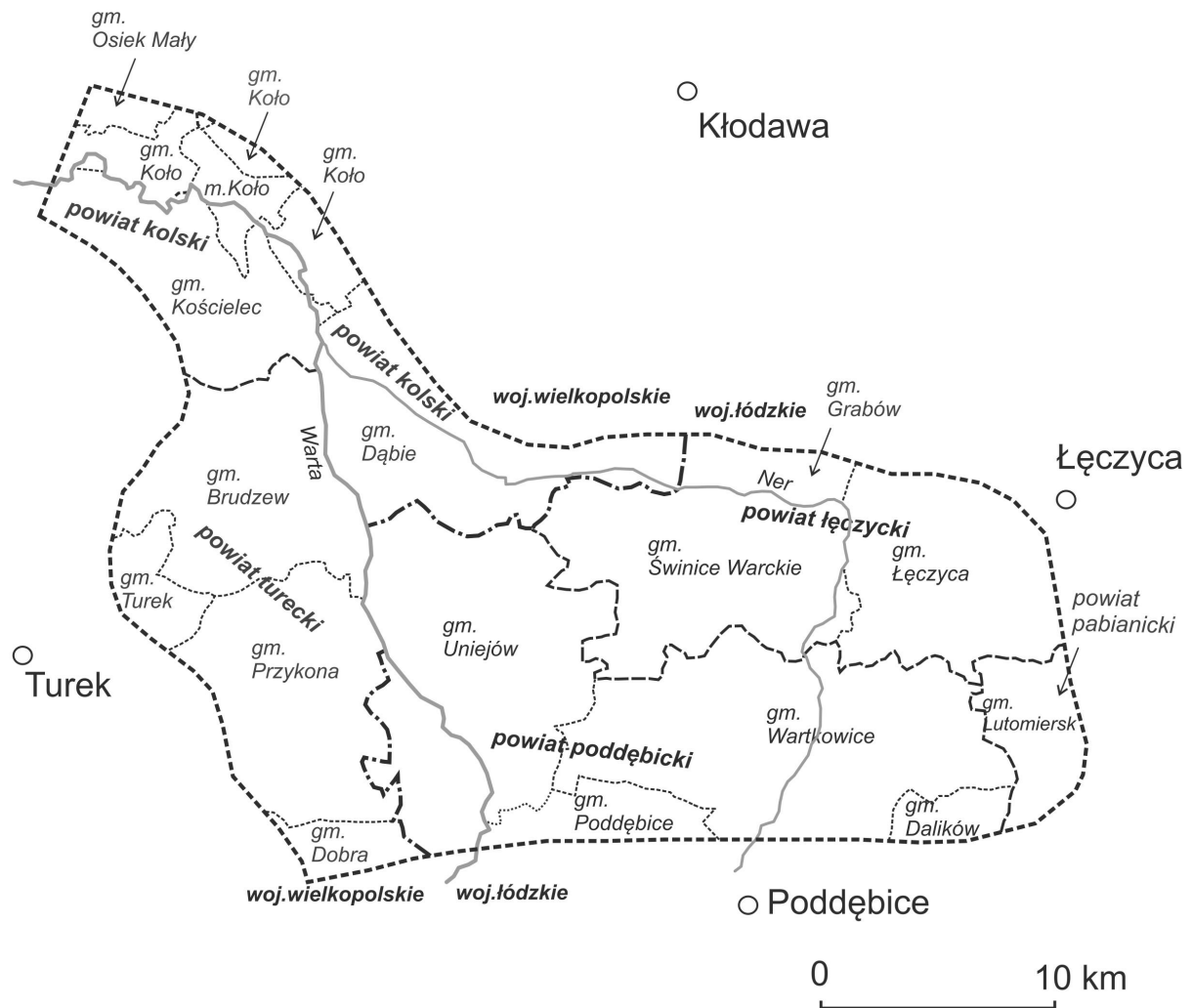

Ryc. 1. Przynależność administracyjna obszaru Kotliny Kolskiej

Źródło: opracowanie własne.

Administrative affiliation of areas within Koło Basin

Source: own work.

Co do zasady rozpoznaniem objęto obszar Kotliny Kolskiej w znaczeniu mezoregionu fizycznogeograficznego, głównie z tego względu, że aktualny podział administracyjny tego obszaru (zwłaszcza w przypadku granic wojewódzkich) nie znajduje uzasadnienia historycznego i geograficznego. W istocie granice te, przynajmniej formalnie, rozdzieliły zasiedziałą tu od dawna społeczność spójnego pod względem krajobrazowym, gospodarczym i kulturowym regionu. Dlatego też w swoich badaniach autorzy zwracali uwagę jedynie na te zasoby kulturowe i przyrodnicze spoza Kotliny Kolskiej, które dla potencjalnego turysty traktującego mezoregion jako bazę wypadową, stanowić mogą atrakcyjny i łatwo dostępny cel wycieczki. 


\section{Uwarunkowania społeczno-gospodarcze rozwoju turystyki wiejskiej}

Sieć osadniczą Kotliny Kolskiej tworzą trzy miasta (Koło, Uniejów i Dąbie) oraz ponad 300 miejscowości wiejskich różnej wielkości. Miasto Koło, położone nad Wartą w północnej części mezoregionu, jest największym jego ośrodkiem miejskim z liczbą ok. 23 tys. mieszkańców. Mniejsze jednostki osadnicze stanowią Uniejów i Dąbie. Pierwsze miasteczko, zlokalizowane w południowej części badanego obszaru, przez większą część swojej najnowszej historii pełniło rolę zaplecza usługowo-handlowego dla otaczających je terenów wiejskich. W ostatnich latach jego ranga bardzo wzrosła jako ośrodka o dynamicznie rozwijającej się bazie turystyczno-usługowej związanej z budową rozległego kompleksu basenów termalnych i uzyskanie w 2012 r. statusu uzdrowiska (Gorczyczewska i Smętkiewicz 2013; Gorączko i Gorączko 2016c). W odległości 10 kilometrów na północ od Uniejowa, na prawym brzegu Neru zlokalizowane jest Dąbie. Szczyt rozwoju gospodarczego tej miejscowości przypadł na wiek XIX, kiedy to stała się ona silnym ośrodkiem rzemieślniczo-handlowym, z blisko pięciotysięczną liczbą ludności. Stan obecny to niewiele ponad 2 tys. mieszkańców. Wśród innych, ważnych ośrodków miejskich (o zróżnicowanej liczbie mieszkańców), położonych w sąsiedztwie Kotliny Kolskiej warto wymienić: Łęczycę (ok. 4 tys. mieszkańców), Kłodawę (blisko 7 tys.), Turek (ok. 28 tys.) oraz Poddębice (blisko 8 tys.). Wybrane dane statystyczne dla powiatów obejmujących swoim zasięgiem obszar Kotliny Kolskiej, dające przybliżony obraz statystyczny poszczególnych jego części, a więc uznane za istotne z punktu widzenia badawczego, zestawiono w tabeli 1.

$\mathrm{Na}$ tle kraju obszar Kotliny Kolskiej charakteryzuje się niską gęstością zaludnienia. Liczba osób przypadających na 1 km² kształtowała się na poziomie 47 i 66 w przypadku powiatów poddębickiego i łęczyckiego (przeciętna wartość wskaźnika dla województwa łódzkiego wyniosła 137 os. $/ \mathrm{km}^{2}$ ) oraz 87 os. $/ \mathrm{km}^{2}$ i 91 os. $/ \mathrm{km}^{2}$ w przypadku powiatów kolskiego i tureckiego (przy przeciętnej wartość wskaźnika dla województwa wielkopolskiego wynoszącej 116 os. $/ \mathrm{km}^{2}$ ). W regionie wyraźnie dominuje ludność wiejska. Mieszkańcy miast stanowią odpowiednio 26\% i 28\% w powiatach poddębickim i łęczyckim (średnia dla województwa łódzkiego wyniosła 63\%) oraz 37\% i 39\% w powiatach kolskim i tureckim (średnia dla województwa wielkopolskiego wyniosła 55\%). Na tym tle wyróżnia się pod względem gęstości zaludnienia i wskaźnika umiastowienia powiat pabianicki, który jednak w przeważającej części funkcjonalnie zaliczany jest do aglomeracji łódzkiej. Należy zwrócić uwagę, że jedyna gmina tego powiatu obejmująca swoim zasięgiem niewielką część Kotliny Kolskiej, jaką jest gmina Lutomiersk, stanowi typowo wiejską jednostkę terytorialną o zagęszczeniu ludności wynoszącym jedynie 61 os./km², pozbawioną ośrodków miejskich na swoim terenie (Dmochowska-Dudek i in. 2015).

Najkorzystniejszą strukturą demograficzną cechuje się powiat turecki, gdzie udział ludności w wieku produkcyjnym i przedprodukcyjnym jest wyraźnie większy niż w pozostałych jednostkach. Również w przypadku powiatu tureckiego notuje się najniższą stopę bezrobocia (nieznacznie wyższa wartość od średniej dla województwa wielkopolskiego), gdy w innych powiatach nadal wyrażana jest ona liczbą dwucyfrową. Niemal cały region cechuje się ujemnym saldem migracji za wyjątkiem powiatu pabianickiego (w tym także gminy Lutomiersk) oraz powiatu poddębickiego. Za miarę przedsiębiorczości na terenie powiatów może być traktowana liczba podmiotów gospodarczych w rejestrze REGON w przeliczeniu na 10 tys. mieszkańców. Generalnie za wyjątkiem powiatu pabianickiego (i gminy Lutomiersk) w rejonie Kotliny Kolskiej wartości tego wskaźnika są znacznie niższe 


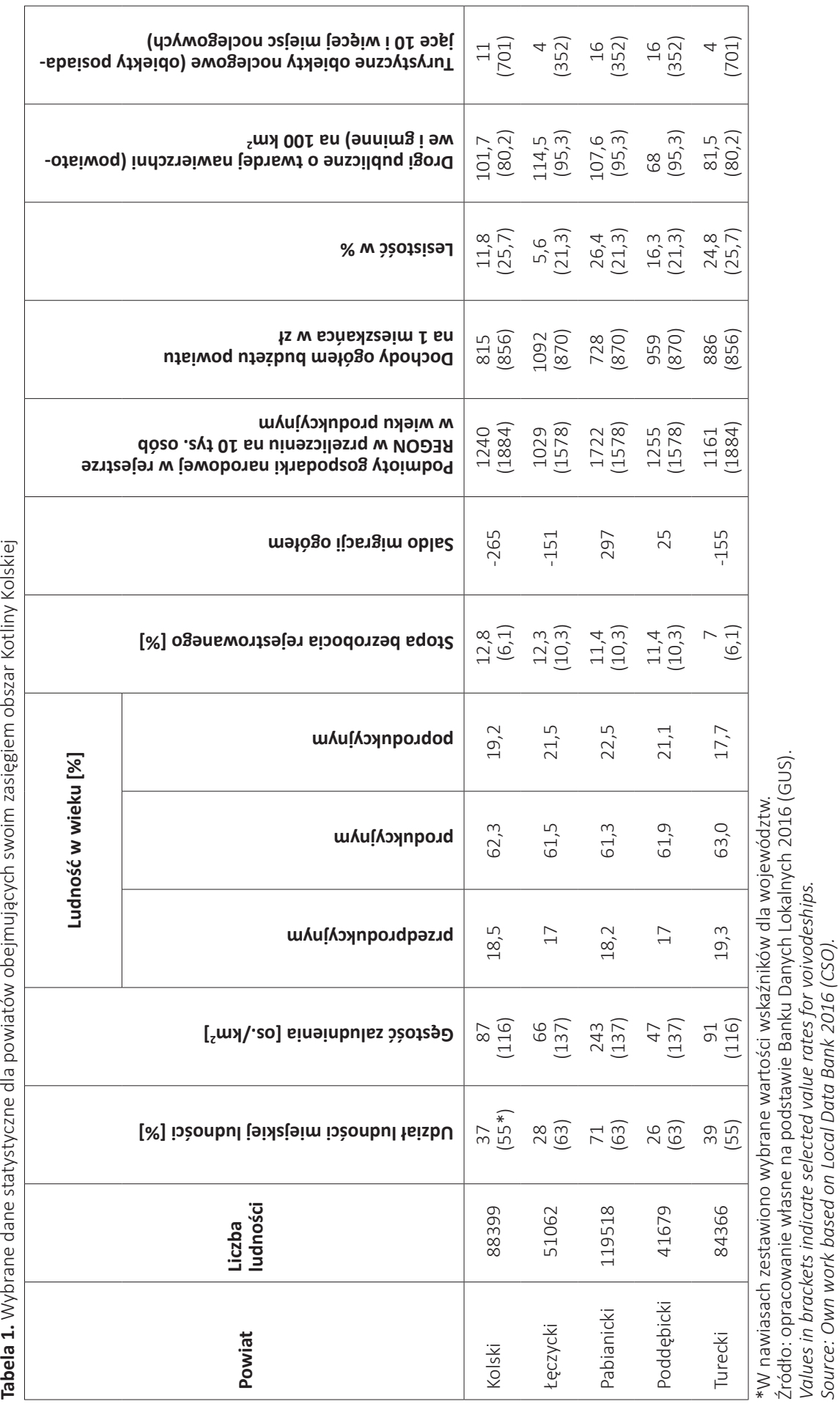


niż przeciętne dla obydwu województw. Natomiast dość przeciętnie na tle województw ukształtowały się dochody budżetu powiatów w przeliczeniu na 1 mieszkańca, poza przypadkiem powiatu łęczyckiego, gdzie w 2015 r. były one wyraźnie wyższe. Stan rozwoju infrastruktury drogowej jest w rejonie Kotliny Kolskiej dość zróżnicowany, na co wskazują wartości wskaźnika długości utwardzonych dróg publicznych, zarówno gminnych jak i powiatowych na $100 \mathrm{~km}^{2}$. Generalnie jest on zdecydowanie wyższy (także w stosunku do wartości przeciętnych dla województw) w przypadku powiatów, na terenie których znajduje się przynajmniej jeden węzeł komunikacyjny o znaczeniu krajowym. Generalnie jednak cały obszar Kotliny Kolskiej cechuje bardzo dobra dostępność komunikacyjna. Przez rozpatrywany obszar przebiega odcinek autostrady A2 o długości około 50 kilometrów, a połączenia z drogami niższego rzędu zapewniają równomiernie rozlokowane węzły znajdujące się w pobliżu Koła, Dąbia oraz Wartkowic. Na ogół bardzo nieliczne (poza terenem miasta Uniejów) są większe turystyczne obiekty noclegowe (posiadające 10 i więcej miejsc noclegowych), co pośrednio wskazuje na słaby ruch turystyczny lub niedostateczny rozwój tego typu infrastruktury.

Rejon Kotliny Kolskiej cechuje się niskim wskaźnikiem lesistości, nawet w porównaniu z przeciętnymi jego wartościami dla województw wielkopolskiego i łódzkiego, które są i tak znacznie niższe niż średnia dla kraju. Szczególnie niewielki udział mają lasy w powierzchni powiatów łęczyckiego (5,6\%) i kolskiego (11,8\%). Poza tym w całym badanym rejonie lasy rzadko stanowią zwarte kompleksy, będąc raczej niewielkimi izolowanymi enklawami. Jednocześnie warunki glebowe w obrębie mezroregionu należy uznać za niezbyt korzystne dla rolnictwa (Stos i Janusz 1986). Charakterystyczny jest duży udział gleb torfowych. Zwartym obszarem ich występowania są dna dolin Warty i Neru, a także ich bezpośrednich dopływów. Wzdłuż Warty występują mady, tworząc mozaikę różnych typów glebowych znacznie różniących się między sobą uziarnieniem, stosunkami wodnymi i budową profilu. Powierzchniowo w Kotlinie przeważają użytki zielone słabe i bardzo słabe na madach na piaskach gliniastych lekkich i luźnych oraz kompleks żytni (żytnio-ziemniaczany) słaby na madach i na piaskach słabo gliniastych. Znaczny jest także udział kompleksu żytniego (żytnio-łubinowego), najsłabszego na madach piaskach luźnych. Mimo prowadzonych od wielu lat prac melioracyjnych znaczna część użytków rolnych narażona jest na podtopienia, zwłaszcza w okresach wezbrań na głównych rzekach regionu. W efekcie produkcja rolnicza prowadzona jest w rozdrobnionych gospodarstwach rodzinnych (Bański 2010), co wpływać musi na jej niską towarowość.

\section{Ocena potencjału turystyczno-kulturowego w rejonie Kotliny Kolskiej}

Rozpoznanie potencjału kulturowo-turystycznego obszaru Kotliny Kolskiej i terenów do niej przyległych metodą zaproponowana przez A. Mikos v. Rohrscheidt (2010) jest niemal pełne. Nie objęto nim jak dotąd jedynie powiatu pabianickiego (południowo-wschodni skraj mezoregionu). Dla powiatów kolskiego i tureckiego raporty waloryzacyjne zostały opracowane na podstawie badań prowadzonych kilka lat wcześniej (Główczyńska 2008; Stefańska 2010). Z tego powodu najprawdopodobniej wymagać one mogą wkrótce aktualizacji, zwłaszcza w zakresie elementów obsługi turystycznej (kategoria II), ale w uzasadnionych przypadkach również dla walorów zakwalifikowanych w kategorii I (Gorączko i Sobczak-Piąstka 2016; Gorączko i Gorączko 2017). Podobne zastrzeżenia nie występują 
w przypadku powiatów łęczyckiego i poddębickiego, które podlegały waloryzacji w roku ubiegłym (Gorączko i Gorączko 2016a, 2016b). W tabeli 2 zestawiono wyniki bonitacji dla wszystkich czterech jednostek.

Tabela 2. Zestawienie wyników waloryzacji turystyczno-kulturowej metodą A. Mikos v. Rohrscheidt (2010) dla powiatów obejmujących swoim zasięgiem Kotlinę Kolską

\begin{tabular}{|c|c|c|c|c|c|c|}
\hline \multirow{2}{*}{ Kategoria } & \multirow{2}{*}{ Podkategoria } & \multicolumn{4}{|c|}{ Powiat } & \multirow{2}{*}{ 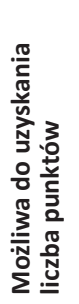 } \\
\hline & & kolski & łęczycki & $\begin{array}{l}\text { poddę- } \\
\text { bicki }\end{array}$ & turecki & \\
\hline \multirow{16}{*}{ 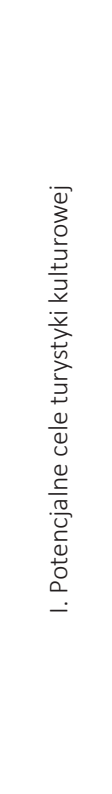 } & I.A Zabytki & 51 & 101 & 87 & 33 & 473 \\
\hline & I.A. a) obiekty sakralne & 32 & 48 & 14 & 16 & 122 \\
\hline & I.A. b) zamki i pałace & 9 & 14 & 19 & 3 & 108 \\
\hline & $\begin{array}{l}\text { I.A. c) inne zabytkowe obiekty architektoniczne } \\
\text { i techniczne }\end{array}$ & 10 & 37 & 48 & 12 & 140 \\
\hline & I.A. d) obiekty militarne & 0 & 2 & 2 & 2 & 18 \\
\hline & I.B. Miejsca historyczne lub znaczące & 26 & 51 & 30 & 9 & 168 \\
\hline & I.B. a) budowle historyczne i monumenty & 22 & 43 & 27 & 7 & 102 \\
\hline & I.B. b) cmentarze historyczne & 4 & 8 & 2 & 2 & 56 \\
\hline & I.B. c) budowle współczesne & 0 & 0 & 1 & 0 & 10 \\
\hline & I.C. Pojedyncze dzieła sztuki & 2 & 18 & 6 & 0 & 72 \\
\hline & I.D. Muzea i wystawy & 27 & 43 & 23 & 2 & 205 \\
\hline & I.E. Eventy kulturowe & 20 & 58 & 58 & 24 & 150 \\
\hline & I.F. Zakłady przemysłowe z ofertą turystyczną & 3 & 0 & 2 & 0 & 16 \\
\hline & I.G. Kulturowo znacząca oferta przyrodnicza & 6 & 6 & 14 & 4 & 53 \\
\hline & I.H. Szlaki kulturowe & 15 & 20 & 20 & 6 & 106 \\
\hline & RAZEM & 151 & 297 & 236 & 78 & 1243 \\
\hline \multicolumn{2}{|c|}{$\begin{array}{l}\text { Ocena potencjału kulturowo-turystycznego (przedział } \\
\text { punktowy) }\end{array}$} & 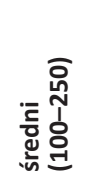 & 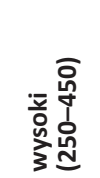 & 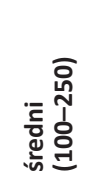 & 竞 $\frac{\bar{o}}{\underline{v}}$ & 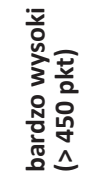 \\
\hline \multirow{5}{*}{ 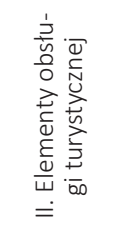 } & II.A. Informacja turystyczna & 4 & 13 & 10 & 0 & 17 \\
\hline & II.B. Infrastruktura turystyczna & 19 & 22 & 50 & 10 & 51 \\
\hline & II.C. Infrastruktura komunikacyjna & 18 & 21 & 19 & 8 & 32 \\
\hline & II.D. Promocja turystyczna & 0 & 2 & 14 & 7 & 20 \\
\hline & RAZEM & 41 & 58 & 93 & 21 & 120 \\
\hline
\end{tabular}




\begin{tabular}{|c|c|c|c|c|c|c|}
\hline \multirow{4}{*}{ 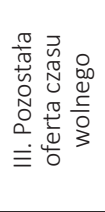 } & III.A. Instytucje Kultury & 2 & 3 & 0 & 2 & 12 \\
\hline & III.B. Atrakcje krajobrazowe & 4 & 4 & 5 & 2 & 14 \\
\hline & $\begin{array}{l}\text { III.C. Oferta sportowa, edukacyjna i } \\
\text { rekreacyjna }\end{array}$ & 7 & 6 & 11 & 6 & 13 \\
\hline & RAZEM & 13 & 12 & 16 & 9 & 39 \\
\hline \multirow{6}{*}{ 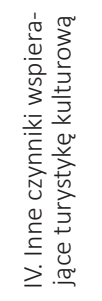 } & IV.A. Instytucje w regionie & 2 & 0 & 0 & 0 & 15 \\
\hline & IV.B. Oferta turystyki zdrowotnej & 0 & 0 & 8 & 0 & 16 \\
\hline & IV.C. Oferta turystyki biznesowej & 6 & 0 & 3 & 0 & 11 \\
\hline & IV.D. Oferta shoppingu & 0 & 0 & 0 & 4 & 11 \\
\hline & $\begin{array}{l}\text { IV.E. Zagraniczne Partnerstwa Miast i } \\
\text { Regionów }\end{array}$ & 2 & 3 & 4 & 0 & 4 \\
\hline & RAZEM & 10 & 3 & 15 & 4 & 57 \\
\hline \multicolumn{2}{|c|}{ SUMA (WSZYSTKIE KATEGORIE) } & 209 & 371 & 360 & 112 & 1453 \\
\hline
\end{tabular}

Źródło: opracowanie własne na podstawie: A.Główczyńska (2009), J. Stefańska (2010), M. Gorączko i A. Gorączko (2016a, 2016b).

Jak wynika z powyższego zestawienia, potencjał turystyczno-kulturowy powiatów obejmujących swoim zasięgiem Kotlinę Kolską jest bardzo zróżnicowany. Najmniej korzystna sytuacja przedstawia się w powiecie tureckim, którego potencjał na podstawie kategorii I „Potencjalne cele turystyki kulturowej” oceniono jako niski (jedynie 78 pkt). Jednostką o dużym potencjale turystyczno-kulturowym jest natomiast powiat łęczycki (297 pkt). Dwa pozostałe powiaty reprezentują mikroregiony o średnim potencjale, przy czym w przypadku powiatu poddębickiego uzyskana liczba punktów (236) jest bardzo bliska wartości stanowiącej górną granicę przedziału.

Wiodące znaczenie dla rozwoju turystyki dziedzictwa kulturowego ma powiat łęczycki (ryc. 2), na terenie którego znajduje się ośrodek osadniczy o wczesnośredniowiecznych korzeniach, w skład którego wchodzi kilka dobrze zachowanych zabytków, unikalnych pod względem architektonicznym i historycznym, nie tylko w skali regionu, ale także całego kraju. Należą do nich: kazimierzowski zamek obronny w Łęczycy oraz pozostałości łęczyckiego grodziska wcześniej będącego przedpiastowskim ośrodkiem władzy plemiennej, a także romańska kolegiata w Tumie (Gorączko i Gorączko 2016a). Dużą atrakcję turystyczną stanowić może zamek biskupów gnieźnieńskich w Uniejowie (jako jedna z najlepiej zachowanych budowli obronnych na terenie województwa łódzkiego i nielicznych tego typu w Polsce użytkowanych przez cały okres istnienia), natomiast o znacznym potencjale pod tym względem można mówić w przypadku pozostałości średniowiecznych zamków w Kole, Besiekierach (gmina Grabów w powiecie łęczyckim) oraz w Borysławicach Zamkowych (gmina Grzegorzew w powiecie kolskim). Dość dobrze w całym mezoregionie i jego sąsiedztwie udokumentowane są etapy rozwoju budownictwa wiejskiego sięgające przynajmniej połowy XIX w. Liczne są tu dwory i rezydencje szlachecko-ziemiańskie, przy czym niestety ich stan zachowania pozostawia wiele do życzenia. Mimo iż w promocyjnych materiałach turystycznych zwykle obiekty te są przedstawiane jako atrakcja godna odwiedzenia, toleruje się ich postępującą dewastację i utrudnioną dostępność. Dotyczy to nawet obiektów, które związane są z biografią osób o znaczeniu krajowym (Gorączko i Gorączko 2017). Wzorcowym przykładem zadbanej siedziby rodów szlacheckich jest późnorenesansowy Pałac Grudzińskich w Poddębicach, laureat 
konkursu Ministra Kultury i Dziedzictwa Narodowego oraz Generalnego Konserwatora Zabytków „Zabytek Zadbany 2016” w kategorii „Rewaloryzacja przestrzeni kulturowej i krajobrazu".

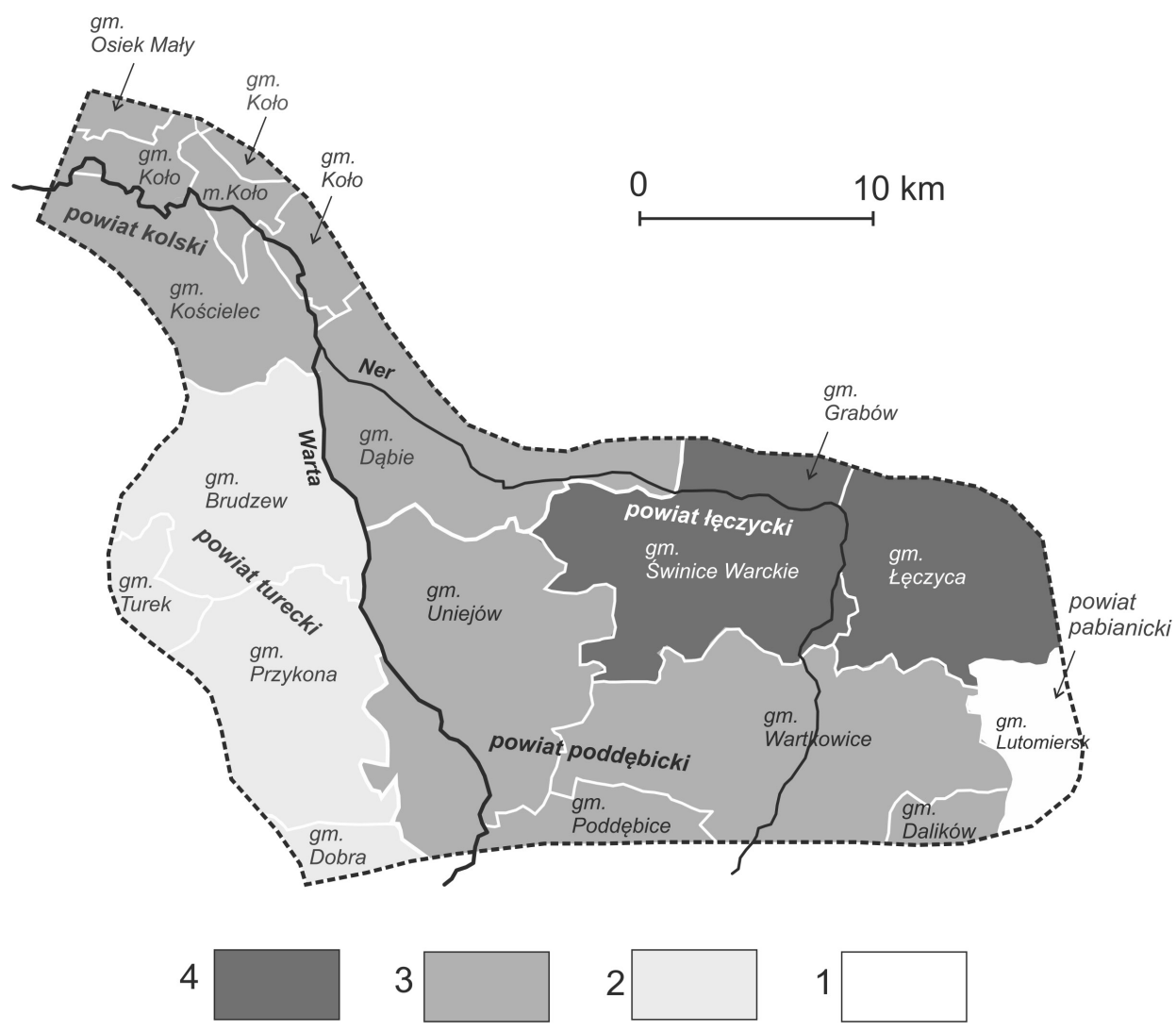

Ryc. 2. Potencjał kulturowo-turystyczny w Kotlinie Kolskiej na podstawie wyników waloryzacji metodą A.Mikos v. Rohrscheidt (2010)

4 - wysoki, 3 - średni, 2 - niski, 1 - brak danych

Źródło: opracowanie własne.

Tourism and cultural potential of Koło Basin, based on the valuation method by A. Mikos v. Rohrscheidt (2010) 4-large, 3-medium, 2-low, 1 - no data.

Source: own work.

Kotlina Kolska wraz z jej bezpośrednim otoczeniem to obszar w obrębie którego do dziś zachowała się tradycyjna zabudowa wiejska o regionalnych cechach materiałowych, konstrukcyjnych i architektonicznych (Gorączko i Gorączko 2013, 2015, 2016c). Począwszy od połowy XIX w. aż do końca lat 60. XX w. na tych terenach przy wznoszeniu zagród powszechnie wykorzystywano lokalny kamień budowlany. Na jego spopularyzowanie wśród miejscowej ludności złożyło się szereg przyczyn. Z jednej strony zaznaczał się tutaj dotkliwy deficyt drewna konstrukcyjnego i surowców ceramicznych, z drugiej zaś łatwo było o dostęp do materiału skalnego nadającego się do zastosowania w budownictwie zagrodowym. W efekcie budynki wzniesione z miejscowego kamienia przez długie lata stanowiły najbardziej charakterystyczny element krajobrazu kulturowego w rejonie Kotli- 
ny Kolskiej. Największa ich liczba zlokalizowana jest w obrębie międzyrzecza Warty i Neru.

Ofertę turystyki dziedzictwa kulturowego uatrakcyjniają stosunkowo liczne placówki muzealne. Za najważniejszą z nich, koordynującą badania naukowe z zakresu historii, archeologii i kultury ludowej ziemi łęczyckiej, należy uznać regionalne muzeum na zamku w Łęczycy. W ostatnich latach na bazie relokowanych obiektów architektury ludowej z terenów mezoregionu powstały dwa skanseny etnograficzne: „Zagroda Młynarska” w Uniejowie (ryc. 3) oraz "Łęczycka Zagroda Chłopska” w Kwiatkówku pod Łęczycą. Dobrze rozpoznawalny w kraju i poza jego granicami jest Obóz Zagłady w Chełmnie nad Nerem (niem. Kulmhof) z okresu II wojny światowej, opisany w „Medalionach” przez Zofię Nałkowską. Na terenie obiektu zlokalizowano niewielkie muzeum poświęcone martyrologii ludności żydowskiej z Kraju Warty oraz łódzkiego getta. We wsi Bronów (gmina Wartkowice) znajduje się Muzeum Oświatowe „Dworek M. Konopnickiej” będące filią Biblioteki Pedagogicznej w Sieradzu. Z kolei w miejscowości Głogowiec niedaleko Świnic Warckich udostępniony został dom rodzinny św. Faustyny. W 2013 r. utworzono Muzeum Miasta Turku im. Józefa Mehoffera (m.in. z ekspozycją etnograficzną i archeologiczno-przyrodniczą), przekształcone z Muzeum Rzemiosła Tkackiego, natomiast w Kole funkcjonuje Muzeum Technik Ceramicznych. Bardzo ciekawą ofertę dla zwiedzających, choć wymagającą bardziej skutecznej niż dotychczas promocji, przygotowała Kopalnia Soli w Kłodawie, udostępniając podziemną trasę turystyczną na głębokości 600 metrów (Gorączko i Gorączko 2012). Również przedsiębiorstwo Geotermia Uniejów prowadzi działalność edukacyjną mającą na celu promocję wykorzystania lokalnych zasobów geotermalnych.

Wszystkie wymienione obiekty mają kluczowe znaczenie dla potencjału turystyczno-kulturowego regionu i jego otoczenia. Natomiast jak dotąd turystycznie niezagospodarowane pozostają bogate tradycje przemysłu górniczego w rejonie Kotliny Kolskiej, tzn. eksploatacji żelaza w Łęczycy, węgla brunatnego pod Turkiem oraz kamienia budowlanego w gminie Uniejów.

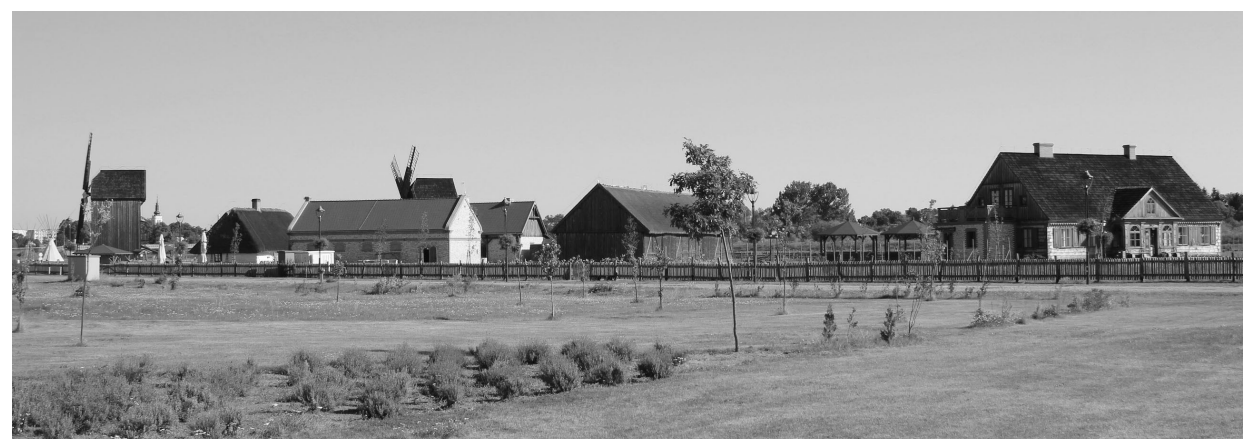

Ryc. 3. Skansen etnograficzny „Zagroda Młynarska” w Uniejowie jako przedsięwzięcie mające na celu zachowanie najcenniejszych obiektów budownictwa ludowego oraz popularyzację wiedzy na temat ginących zawodów Wiejskich (fot. M. Gorączko)

Open-air ethnographic museum "Zagroda Młynarska" in Uniejów, as an example of an enterprise aimed at the preservation of the most valuable objects of rural architecture and popularization of knowledge about extinct rural professions (photo by M. Gorqczko)

Potencjał powiatów silnie zaznacza się w dziedzinie turystyki religijnej. Do szczególnie atrakcyjnych obiektów należą: wspomniana wcześniej kolegiata w Tumie koło Łęczycy (jedna z najstarszych na terenie kraju świątyń), Sanktuarium Urodzin i Chrztu Św. Fausty- 
ny i Klasztor Sióstr Bożego Miłosierdzia w Świnicach Warckich (Suliborski i Kulawiak 2016), Sanktuarium i Pustelnia Błogosławionego Bogumiła w Dobrowie, klasztor bernardynów w Kole oraz klasztor i kościół bernardynów w Łęczycy. Na terenie powiatów znajduje się szereg historycznych kościołów z zabytkowym wyposażeniem, z których najdawniejszą metrykę ma kolegiata w Uniejowie (XIV w.). Stosunkowo liczne są wiejskie kościoły z XVIII w., stanowiące przykłady dobrze utrzymanej drewnianej architektury sakralnej. Dotyczy to m.in. takich miejscowości, jak Kałów, Budzynek, Tur i Brodnia (powiat poddębicki), Topola Królewska, Tum, i Leźnica Mała (powiat łęczycki), Malanów i Wyszyna (powiat turecki) oraz Grzegorzew (powiat kolski). Cały mezoregion od kilkudziesięciu już lat znajduje się na szlaku pielgrzymkowym biegnącym z terenu Pomorza i Kujaw w kierunku Częstochowy. Nie bez znaczenia jest również stosunkowo bliskie jego położenie w stosunku do Lichenia i Kalisza, dwóch znaczących ośrodków kultu religijnego.

$\mathrm{Na}$ bazie tych historycznych zasobów budowana jest bogata oferta eventowa, przy czym zdecydowanie pod tym względem przoduje gmina Uniejów. Wystarczy stwierdzić, że w kalendarzu imprez i wydarzeń zaplanowanych na jej terenie w 2016 r. znalazło się 168 pozycji, co oznacza, że odbywały się one przeciętnie co dwa, trzy dni (Gorączko i Gorączko 2016b). Zasięg ogólnopolski i międzynarodowy miało 28 imprez, natomiast regionalny i wojewódzki 23. Znaczna część z nich stanowi wydarzenia cykliczne, posiadające już pewną tradycję. Do wydarzeń cieszących się w rejonie największą popularnością należą turnieje rycerskie połączone z jarmarkami średniowiecznymi na zamkach w Uniejowie, Łęczycy i Besiekierach, Festiwal Muzyki i Tańca Indian Ameryki Północnej „Pow Wow” w Uniejowie, a przede wszystkim Boże Ciało w Spycimierzu, gdzie w dniu procesji układane są przez mieszkańców wsi dywany kwietne (ryc. 4). Zabytkowe wnętrza, np. kościołów w Łęczycy, Tumie i Uniejowie, ale także dziedzińce zamków są miejscem organizowania regularnych eventów kultury wysokiej (zwykle koncertów).

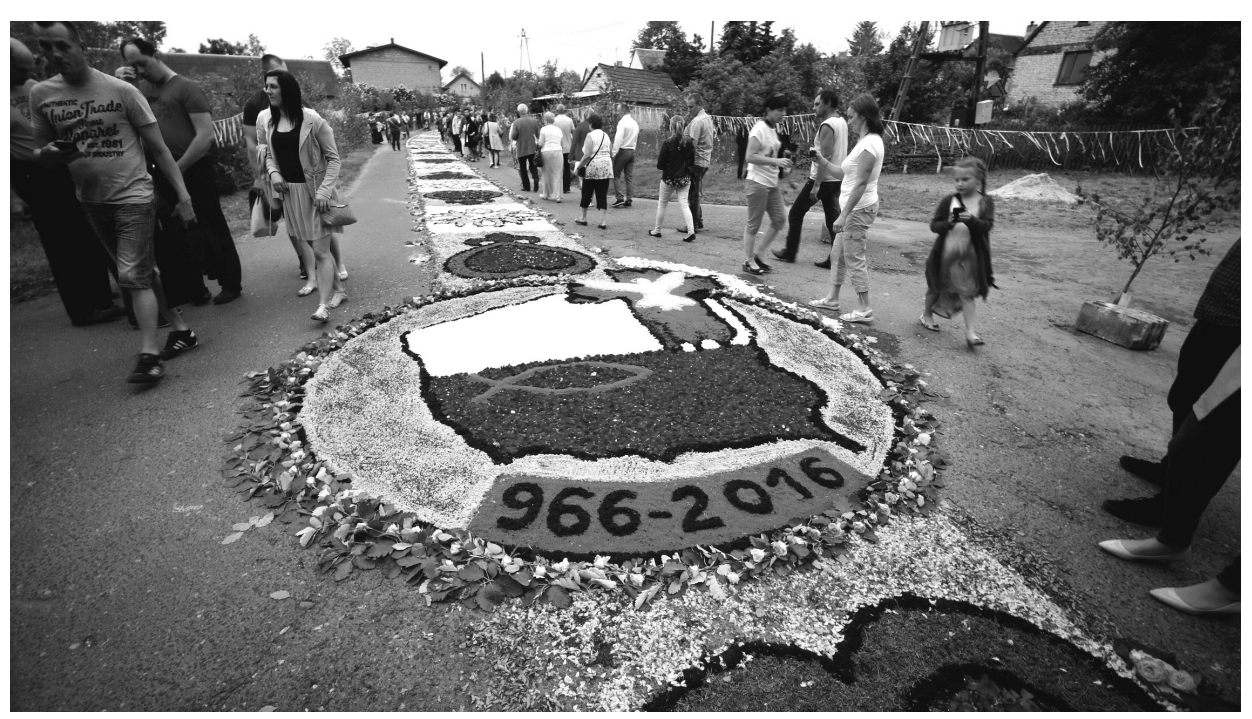

Ryc. 4. Święto Bożego Ciała w Spycimierzu połączone z układaniem kwietnych dywanów - przykład turystycznie atrakcyjnego wydarzenia integrującego mieszkańców wsi (fot. M. Bartosiak) Celebrations of Corpus Christi combined with weaving flower carpets in the Spycimierz village-example of an activity which is both attractive to tourists and helps in integration of local inhabitants (photo by M. Bartosiak) 
Dotarcie do najciekawszych miejsc w rejonie Kotliny Kolskiej umożliwiają liczne szlaki turystyczne, piesze, samochodowe, rowerowe, ale również konne. Znaczna część z nich to oznakowane szlaki realne, inne mimo iż są szlakami wirtualnym zostały w wystarczającym stopniu opisane w folderach turystycznych. Do najważniejszych szlaków turystycznych należą: "Nadwarciański Szlak Rowerowy” (w powiecie kolskim), „W centrum Polski” (rowerowy w powiecie łęczyckim), "Łódzka Magistrala Rowerowa” (w powiatach łęczyckim i kolskim), „Łódzki Szlak Konny im. mjr Henryka Dobrzańskiego Hubala” (w powiatach łęczyckim, poddębickim i pabianickim), „Do Gorących Źródeł” (rowerowy w powiecie poddębickim), „Szlak Wschodnioeuropejskiego Frontu I Wojny Światowej na Ziemiach Polskich" (samochodowy w powiatach łęczyckim, poddębickim, kolskim i pabianickim), "Szlak Marii Konopnickiej” (pieszy w powiatach poddębickim i łęczyckim), „Szlak Świętej Faustyny Kowalskiej” (pieszy w powiatach łęczyckim i poddębickim) oraz „W Królestwie Diabła Boruty" (rowerowy w powiecie łęczyckim). Warto zwrócić uwagę, że poza dwoma wyjątkami wymienione wyżej trasy nie przekraczają granic wojewódzkich, utrwalając w ten sposób dokonany w 1999 r. administracyjny podział mezoregionu.

\section{Ocena walorów przyrodniczych w rejonie Kotliny Kolskiej wspierających turystykę kulturową}

Lokalnym zasobem Kotliny Kolskiej o potencjalnie dużym znaczeniu dla turystyki jest występująca tutaj sieć rzeczna, głównie odcinek środkowej Warty. Koryto rzeki mimo przeprowadzonych prac regulacyjnych zachowało sporo ze swojego meandrującego charakteru. Rzeka od Uniejowa do okolic Koła jest dostępna dla łodzi wiosłowych oraz lekkich łodzi motorowych lub żaglowych o zanurzeniu nieprzekraczającym 40 cm (Lityński 2007). Potencjalnie ważnym szlakiem kajakowym jest Ner, prawobrzeżny dopływ Warty, głównie ze względu na fakt, iż bierze on swój początek w obrębie aglomeracji łódzkiej, a tradycje spływów tą rzeką sięgają jeszcze okresu międzywojennego. Podstawowym problemem ograniczającym rozwój turystyki wodnej w regionie jest niemal zupełny brak infrastruktury służącej do jej uprawiania, a przecież oczekiwania przeciętnych użytkowników szlaku kajakowego niekoniecznie muszą być wygórowane i trudne do spełnienia. Wystarczy przygotować dogodne wyjście na brzeg, trawiaste lub piaszczyste podłoże, pomost stały lub pływający, trawiaste najlepiej zacienione miejsce na rozbicie namiotów, przenośną toaletę, wydzielone miejsce na ognisko czy stoły i ławy do przyrządzania posiłków. Tego typu działania udało się osiągnąć jedynie w przypadku Warty w Uniejowie i w Kole. Natomiast wzdłuż Neru takie udogodnienia nie występują. Coraz mniejszą barierą dla uprawiania turystyki wodnej jest stan czystości rzek. Dobrą jakością charakteryzują się wody Warty. Z kolei potencjał ekologiczny wód w zlewni Neru, choć klasyfikowany jako umiarkowany (w dolnym biegu) lub niski (na pozostałym odcinku) - odznacza się w ostatnich latach dużą poprawą.

Kotlina Kolska to obszar położony na południe od maksymalnego zasięgu najmłodszego zlodowacenia, przez co brak tutaj jezior, za wyjątkiem starorzeczy występujących w dolinie Warty i Neru. Są to jednak akweny niewielkie i płytkie, będące w zaawansowanym stadium zarastania, przez co strefa brzegowa nie nadaje się do turystycznego i rekreacyjnego zagospodarowania. Szansa na poprawę tej sytuacji istnieje w zachodniej części regionu, gdzie prowadzona jest odkrywkowa eksploatacja węgla brunatnego. Pla- 
nuje się, że po zaprzestaniu działalności górniczej istniejące wyrobiska częściowo zostaną przekształcone w zbiorniki wielofunkcyjne (Orlikowski i Szwed 2011). Na chwilę obecną oddano do użytku niewielki, ale głęboki zbiornik śródleśny Bogdałów oraz zbiornik Przykona. Z mniejszych, antropogenicznych zbiorników wodnych nadal niezagospodarowane (pomimo korzystnych warunków do lokalizacji kąpielisk) pozostają obiekty (w rejonie wsi Sobótka w gminie Dąbie), powstałe w wyniku eksploatacji kruszywa użytego przy budowie autostrady. Co ciekawe, na badanym obszarze dziwić może niemal zupełny brak stawów hodowlanych, biorąc pod uwagę, że występują w Kotlinie bardzo korzystne warunki gruntowo-wodne.

Przyroda Kotliny Kolskiej objęta jest różnymi formami ochrony. Zarówno dolina Warty, jak i dolina Neru znajdują się na liście obszarów objętych programem Natura 2000 o statusie obszarów specjalnej ochrony ptaków (PLB100001 - Pradolina Warszawsko-Berlińska i PLB300002 - Dolina Środkowej Warty). Jednocześnie wzdłuż wymienionych rzek ochronie podlega krajobraz w ramach Obszaru Chronionego Krajobrazu Pradoliny Warszawsko-Berlińskiej oraz Uniejowskiego Obszaru Chronionego Krajobrazu. Działania te wychodzą naprzeciw oczekiwaniom amatorów turystyki ornitologicznej (tzw. birdwaching), która wzorem krajów Europy Zachodniej zdobywa w Polsce coraz większą popularność (Janeczko i Anderwald 2011; Kordowska i Kulczyk 2014). Chociażby z tego względu warto rozważyć uwzględnienie w opracowanym przez A. Mikos v. Rohrscheidt (2010) arkuszu waloryzacyjnym obok parków krajobrazowych także obszarów sieci Natura 2000 (ryc. 5).

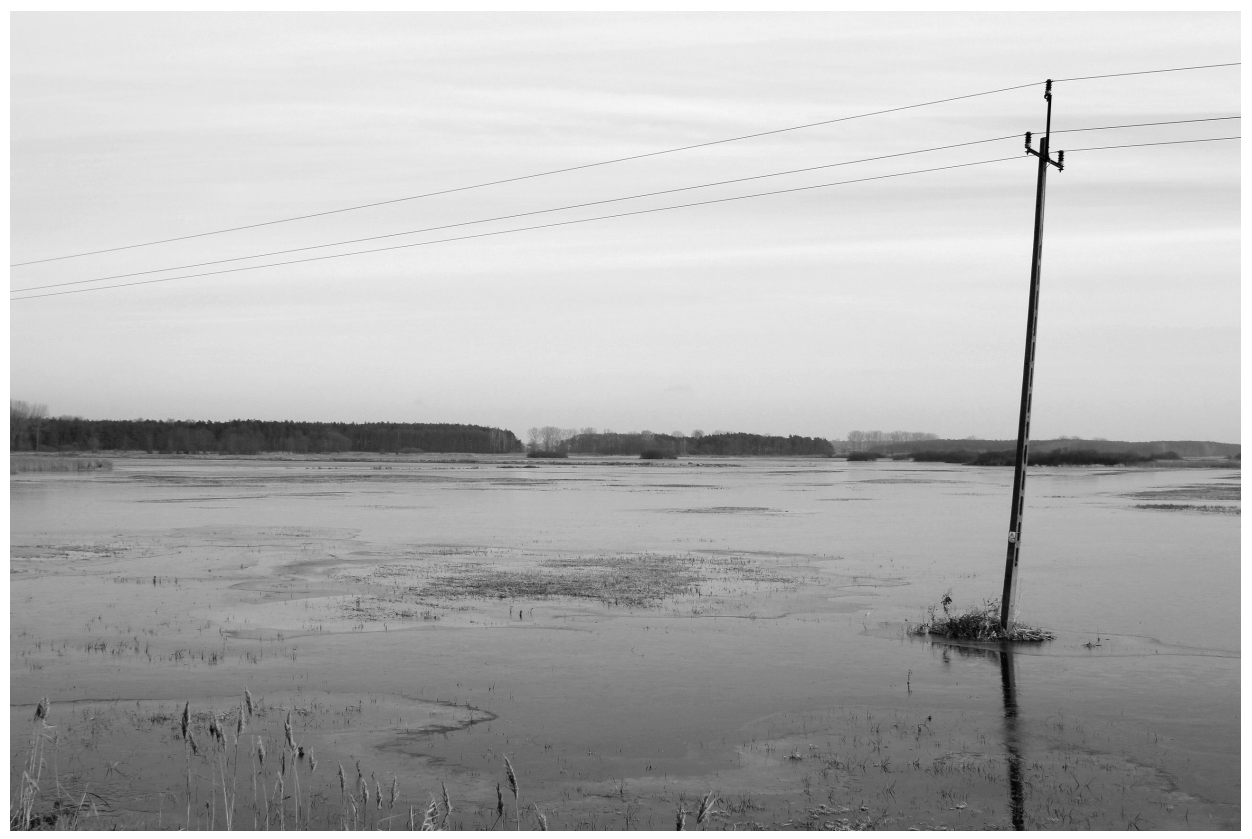

Ryc. 5. Uciążliwe dla rolnictwa rozlewiska w dolinie Neru okazały się być cennym siedliskiem dla awifauny. Obecnie podlegają one ochronie w ramach sieci NATURA 2000 (fot. M. Gorączko).

Flooding areas in Ner River valley which have caused difficulties for the agriculture, turned out to be a valuable nesting place for avifauna. Currently the area is under environmental protection and is included in NATURA 2000 network (photo by M. Gorqqczo) 
Niewątpliwie jednak największą atrakcją bazującą na miejscowych zasobach przyrodniczych jest uzdrowisko Uniejów, najmłodszy, bo ustanowiony w 2012 r. kurort w Polsce. Podstawą do nadania statusu uzdrowiska obejmującego swoim zasięgiem miasto Uniejów oraz sołectwa Spycimierz, Spycimierz-Kolonia, Zieleń i Człopy były właściwości miejscowych termalnych wód leczniczych. Inną atrakcją występującą w pobliżu Kotliny Kolskiej, we wsi Borysew koło Poddębic, jest jeden z największych w Polsce prywatnych ogrodów zoologicznych. Dzięki stworzeniu ciekawej oferty (unikalne zwierzęta na skalę światową) oraz jej skutecznej promocji obiekt ten generuje ruch turystyczny szacowany na 200 tys. osób rocznie.

\section{Ocena aktualnej oferty agroturystycznej i turystycznej gospodarstw wiejskich Kotliny Kolskiej}

Etap prac polegający na ustaleniu liczby wiejskich obiektów wypoczynkowych zakończył się zdiagnozowaniem w obrębie badanego obszaru 25 jednostek świadczących usługi dla turystów. Okazało się jednak, że analizie można poddać tylko 13 ofert, albowiem z różnych względów pozostałe usługi przestały funkcjonować lub okazały się niepełniącymi funkcji turystycznych. Spośród ogółu wyłonionych do badań działalności wypoczynkowo-rekreacyjnych cztery okazały się agroturystycznymi (związanymi z czynnym gospodarstwem rolnym - wypoczynek u rolnika), a pozostałe kwaterami turystycznymi na wsi (wypoczynek na wsi, niekoniecznie związany z pobytem u rolnika). Badania wykazały słabe zaangażowanie właścicieli w proces organizowania gościom odpowiednich nie tylko warunków pobytu (tab. 2), ale również atrakcji, które opierałyby się na dziedzictwie kulturowym wsi. Tylko ci akcentujący duże przywiązanie do ziemi (4 obiekty) budują produkty agroturystyczne na bazie swojego gospodarstwa, ale nie są one oparte np. na regionalnych zwyczajach kulinarnych Kotliny Kolskiej. Raczej związane są z promocją ekologicznych produktów - jaj, serów, masła, bezglutenowego orkiszowego pieczywa, jak również wędzonych (wędlin, drobiu, ryb), wegetariańskich i dietetycznych. Usługodawcy traktują tego typu działania jako wyróżnik swojej kwatery, dając możliwość nie tylko ich degustacji oraz kupna, ale także wytworzenia na miejscu w ramach organizowanych przez siebie warsztatów (np. serowarskich). Wizerunek tych ofert wzmacnia fakt, że gospodarze ci wyrażają chęć współpracy z miejscową ludnością oraz kooperacji z innymi osobami trudniącymi się podobnymi usługami turystycznymi na wsi. Takie współdziałanie dotyczy przede wszystkim wymiany towarów (np. wyrobów mleczarskich, wędliniarskich) oraz usług (np. wypożyczenia rowerów). Z kolei produktem turystycznym bardziej nawiązującym do dziedzictwa kulturowego wsi jest zorganizowanie wypoczynku gościom w dwóch chatach, utrzymanych w XIX-wiecznym stylu. Jak podkreślają autorzy tego pomysłu, umiejscowienie ich w otoczeniu zieleni, z dala od miejskiego zgiełku jest głównym atrybutem ich oferty. Z pojedynczych przykładów warto też podać przykład starego domu (zbudowanego w lokalnym stylu z miejscowego białego wapienia), w którym organizowane są warsztaty o różnej tematyce. Właściciele udostępniają go pomysłodawcom ciekawych lekcji, z nastawieniem, że będzie on miejscem „spotkań wielu wspaniałych, pełnych pasji ludzi, lubiących wyzwania, połączone z pragnieniem działania dla własnego rozwoju, miłością do natury i otwartością na innych". Inni usługodawcy (4 obiekty) uznali posiadanie hodowli koni za atrybut swojej oferty. Dysponując odpowiednim zapleczem infrastrukturalnym i kadrą instruktorską, za- 
pewniają turystom jazdę konną lub jej naukę. Dzięki pobliskim szlakom konnym organizują też obozy nauki jazdy konnej oraz kilkudziesięciokilometrowe rajdy po Wielkopolsce dla profesjonalnych już jeźdźców. Zdaniem usługodawców miłośnicy koni mają dzięki takim aktywnościom znakomitą okazję poznać urok pobliskich wiosek, lasów i jezior. Pozostali właściciele wiejskich obiektów turystycznych (3 obiekty) nie posiadają już tak specjalistycznych ofert, nakierowanych na określonego nabywcę. Grzybobranie, wędkowanie, sąsiedztwo szlaków turystycznych i pieszych to atrakcje nastawione głównie na wypoczynek aktywny.

Usługodawcy z terenu Kotliny Kolskiej bardzo często podkreślali, że w bezpośrednim sąsiedztwie ich posesji brak jest zbiorników wodnych bądź cieków, co może wpływać na jakość oferty. Częściej kwatery położone były w sąsiedztwie lasu (do 0,5 km od domostw). Niemniej, jak podkreśla J. Cichowska (2011), walory przyrodnicze (zwłaszcza duża odległość od zbiorników wodnych i cieków oraz lasów) nie muszą stanowić wyznacznika w tworzeniu usług turystycznych na wsi. Najważniejsze jest, aby mieszkańcy wsi wychodzili naprzeciw różnym trudnościom i chcieli budować usługę w oparciu o posiadane zasoby i swoje umiejętności. Trzeba jednak podkreślić, że na elementy atrakcyjności swojego obiektu w postaci ciszy, spokoju i walorów przyrodniczych otoczenia zwraca uwagę praktycznie każda z badanych osób. Mimo że są to tylko subiektywne odczucia właścicieli, niemniej w promocji oferty istotne. J. Cichowska (2014) w swoich badaniach zauważa, że organizatorzy wypoczynku na wsi niestety rzadko przekazują przyszłym urlopowiczom pełną informację o walorach przyrodniczych

W trakcie prowadzonych badań nie udało się wyselekcjonować ofert, które pokrywałyby się z myślą przewodnią pracy badawczej, a mianowicie nawiązaniem do dziedzictwa obszarów wiejskich. Żaden z usługodawców nie gromadził na swoich posesjach starego sprzętu i urządzeń nawiązujących do kultury regionu, nikt nie hołdował ginącym zawodom i nie podkreślał ważności i tradycji zwyczajów panujących na wsi. Jednocześnie nie wskazywał turystom ciekawych miejsc i obiektów, które warto by odwiedzić przy okazji pobytu w ich gospodarstwie.

\section{Perspektywy rozwoju wiejskiej infrastruktury turystycznej w Kotlinie Kolskiej}

Od kilku lat na obszarze Kotliny Kolskiej mamy do czynienia z dynamicznym wzrostem napływu turystów. Głównym katalizatorem tego zjawiska jest miasto Uniejów, rocznie odwiedzane przez ponad 400 tys. osób (Gorączko i Gorączko 2016c). Jak się wydaje, sytuacja ta powinna sprzyjać rozwojowi infrastruktury turystyki wiejskiej, a zwłaszcza wiejskiej bazy noclegowej. W dalszych rozważaniach, przyjęto następujące założenia:

1) Na tle kraju Kotlina Kolska cechuje się niskimi walorami przyrodniczymi (w tym zwłaszcza krajobrazowymi), co przekłada się na bardzo niską ocenę walorów estetycznych tego regionu. Na szerszą skalę nie mogą więc one stanowić głównego motywu w planowaniu pobytów turystycznych w regionie. Rolę taką w Kotlinie Kolskiej mogą natomiast pełnić walory kulturowe, materialne i niematerialne zarówno tradycyjne, jak też niedawno wykreowane.

2) Powodzenie przedsięwzięć z zakresu organizacji punktów wiejskiej bazy noclegowej jest uzależnione od ich położenia w stosunku do terenów o znacznym potencjale turystyczno-kulturowym, według zasady: im większe oddalenie od obszaru cechu- 
Tabela 2. Oferta agroturystyczna i turystyczna gospodarstw wiejskich Kotliny Kolskiej

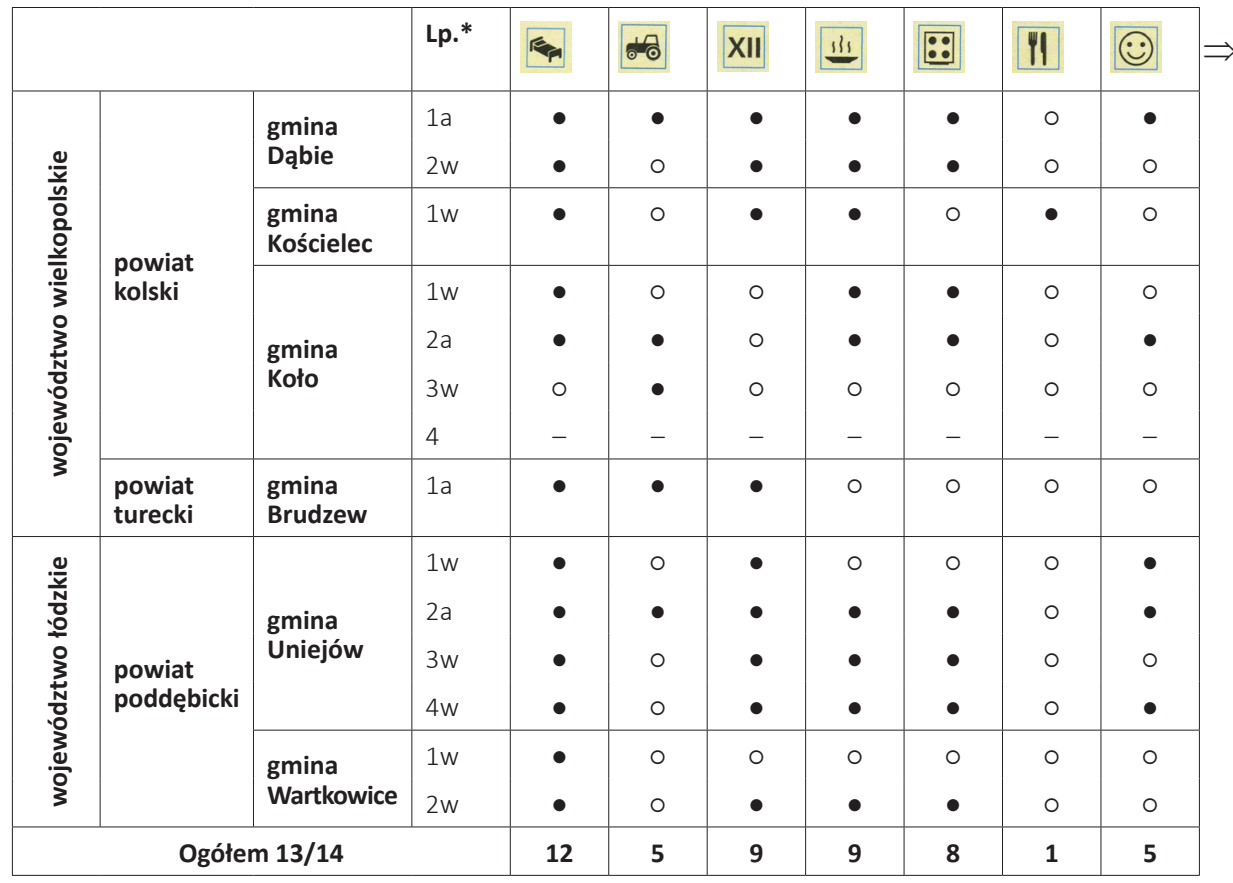

*Lp. - liczba początkowa gospodarstw wg powiatów i gmin, „a” - gospodarstwo agroturystyczne, „w” - turystyka wiejska „•" - z usługi można skorzystać, „O” - brak usługi, „,-" - brak możliwości skontaktowania się z właścicielami, **atrakcje (hodowla strusi, polowanie, żeglowanie, grzybobranie itp.), imprezy (ogniska z atrakcjami, wycieczki piesze i rowerowe itp.), unikalny standard, regionalne potrawy, inny (skansen, leczenie niekonwencjonalne, kursy malarstwa, nauka gry na instrumentach itp.)

\section{Objaśnienia:}

\section{możliwość noclegu}

czynne gospodarstwo rolne

XII całoroczność oferty

ili nocleg z pełnym wyżywieniem

$\because$ przygotowanie innych posiłków

II restauracja (do 0,5 km)

(ن) plac zabaw dla dzieci

jazda konna (na miejscu)

kąpielisko (do 0,5 km) t możliwość wędkowania (na miejscu)

wypożyczalnia rowerów

t

TV dostęp do TV (sala telewizyjna)

$\rightarrow$ przyjazd ze zwierzętami

(7) znajomość języków obcych

$\mathbf{P}$ parking

możliwość spędzania świą

cechy wyróżniające usługę

Źródło: opracowanie na podstawie przeprowadzonych rozmów telefonicznych z właścicielami obiektów agroturystycznych i turystycznych na wsi w 2016 r. 


\begin{tabular}{|c|c|c|c|c|c|c|c|c|c|c|}
\hline ofis & 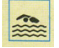 & 1 & $\nabla$ & 境 & TV & $\boldsymbol{A}^{+}$ & (7) & $\mathbf{P}$ & 瓮 & $\square_{* *}$ \\
\hline • & 0 & • & $\bullet$ & • & $\bullet$ & • & • & • & $\bullet$ & • \\
\hline 0 & 0 & ० & ○ & o & ○ & • & • & • & • & 0 \\
\hline 0 & 0 & ○ & ○ & ○ & • & • & • & • & • & • \\
\hline o & o & O & ○ & • & • & • & • & $\bullet$ & • & • \\
\hline 0 & 0 & 0 & $\bullet$ & • & o & • & $\bullet$ & $\bullet$ & ○ & 0 \\
\hline • & 0 & o & ○ & • & 0 & ○ & ○ & • & ○ & • \\
\hline- & - & - & - & - & - & - & - & - & - & - \\
\hline ० & O & O & • & o & • & ○ & ○ & $\bullet$ & ○ & o \\
\hline • & o & O & ○ & ○ & o & ○ & ○ & • & ○ & • \\
\hline 0 & 0 & $\bullet$ & $\bullet$ & • & $\bullet$ & $\bullet$ & ○ & • & $\bullet$ & $\bullet$ \\
\hline 0 & 0 & O & ○ & 0 & o & ○ & o & ○ & ○ & • \\
\hline • & 0 & • & ○ & ○ & • & • & ○ & • & • & • \\
\hline ० & 0 & O & • & $\bullet$ & ○ & • & ○ & • & ○ & o \\
\hline • & o & $\bullet$ & ○ & $\bullet$ & 0 & ○ & $\bullet$ & • & • & • \\
\hline 5 & 0 & 4 & 4 & 7 & 6 & 8 & 6 & 12 & 7 & 9 \\
\hline
\end{tabular}


jącego się znaczną atrakcyjnością kulturową tym mniejsza szansa na przetrwanie obiektu na rynku usług turystycznych i odwrotnie.

Pod uwagę wzięto gminy, których obszar przynajmniej częściowo zaliczany jest do Kotliny Kolskiej.

Potencjał kulturowo-turystyczny miast i otaczających je gmin wiejskich, ze względu na istniejące w ich przypadku silne powiązania historyczne, gospodarcze i społeczne został oceniony łącznie poprzez zsumowanie należnych punktów.

Podstawą oceny lokalnych walorów kulturowych w poszczególnych gminach Kotliny Kolskiej była szczegółowa analiza raportów dotyczących potencjału turystyczno-kulturowego sporządzonych dla powiatów (Główczyńska 2009; Stefańska 2010; Gorączko i Gorączko 2016a, 2016b). Określono w ten sposób udział poszczególnych gmin w najważniejszej z punktu widzenia waloryzacji części (Mikos v. Rohrscheidt 2010), odnoszącej się do potencjalnych celów turystyki kulturowej (kategoria I raportu).

Wyniki przeprowadzonej w oparciu o powyższe założenia analizy uwypukliły znaczne dysproporcje pod względem aktualnego potencjału turystyczno-kulturowego w Kotlinie Kolskiej (ryc. 6). Przewiduje się, że sytuacja ta będzie miała istotny wpływ na kierunki rozwoju infrastruktury turystycznej na terenach wiejskich regionu. Najkorzystniejsze warunki dla rozwoju wiejskiej bazy turystycznej występują w gminie miejsko-wiejskiej Uniejów (144 punkty) oraz w gminie wiejskiej i gminie miejskiej Łęczyca (łącznie 134 punkty). Dla pierwszej jednostki uzyskano ponad 60\% punktów przyznanych w sumie dla całego powiatu poddębickiego (potencjał średni, ale bardzo zbliżony do wysokiego). Wskazuje to na znaczną na tym terenie koncentrację atrakcyjnych turystycznie walorów kulturowych. Co ciekawe, kapitał początkowy gminy w tym względzie jeszcze kilkanaście lat temu przedstawiał się dość skromnie. Składały się na niego przede wszystkim zaniedbane i słabo promowane na zewnątrz zabytki oraz nieliczne wydarzenia kulturowe, co najwyżej o zasięgu lokalnym. W przypadku gminy Uniejów obiekty noclegowe na terenach wiejskich mogą stanowić atrakcyjną alternatywę dla rozwijającej się szybko w obrębie miasta bazy hotelowej (Gorączko i Gorączko 2016b). Z kolei udział rejonu Łęczycy (gmina miejska i wiejska) w sumarycznej ocenie walorów dla powiatu łęczyckiego jest co prawda niższy niż 50\%, ale należy pamiętać, że dotyczy to powiatu o dużym potencjale turystyczno-kulturowym. Dodatkowo znaczna część pozostałych walorów znajduje się na terenie gminy Góra Św. Małgorzaty bezpośrednio przyległej do miasta Łęczyca (np. romańska archikatedra i wczesnośredniowieczne grodzisko w Tumie oraz skansen w Kwiatkówku). Podobnie więc jak samo miasto Łęczyca byłyby one łatwo dostępne przynajmniej dla potencjalnych turystów z obszaru wschodniej części Kotliny Kolskiej.

Jak się wydaje, najmniej sprzyjające warunki dla turystycznej aktywizacji ludności wiejskiej występują w powiecie tureckim. Decyduje o tym niski potencjał turystyczno-kulturowy tego obszaru, przy jednocześnie bardzo dużej koncentracji walorów z tego zakresu wyłącznie na terenie miasta Turek (jedynie 56 punktów stanowiących ponad 70\% punktów dla całego powiatu). Wyjątkiem jest gmina Przykona, pomimo braku własnych walorów kulturowo-turystycznych. Sąsiedztwo z gminą Uniejów, duża lesistość (ok. 25\%) oraz obecność pokopalnianych zbiorników wodnych przystosowanych do rekreacji (na terenach pozbawionych jezior) to główne czynniki, które mogą przyczynić się do rozwoju wiejskiej infrastruktury turystycznej na tym terenie.

Spośród pozostałych jednostek gminnych żadna nie posiada wystarczającego potencjału turystyczno-kulturowego, aby w oparciu o niego liczyć na wzrost znaczenia usług 
turystycznych. W niektórych przypadkach jednak mogą one wykorzystać bezpośrednie sąsiedztwo z jednostkami wiodącymi pod tym względem. Wydaje się, że mieszkańcy gminy Dąbie (18 punktów) powinni skłaniać się ku ośrodkowi uniejowskiemu, natomiast w przypadku gminy Grabów (36 punktów) ku ośrodkowi łęczyckiemu. Dogodne położenie pomiędzy Uniejowem i Łęczycą oraz promocja postaci św. Faustyny w strategii marketingowej obydwu miast stanowi atut gminy Świnice Warckie (zasoby własne gminy wycenione na 39 punktów). Podobnie korzystnym położeniem charakteryzuje się gmina Wartkowice. Odrębnego potraktowania wymagają gminy wiejskie wokół miasta Koło, które stopniowo przeobrażają się w typową strefę podmiejską, co w połączeniu z niskim potencjałem turystyczno-kulturowym powiatu kolskiego raczej nie sprzyja tworzeniu oferty usługowej z zakresu agroturystyki i turystyki wiejskiej.

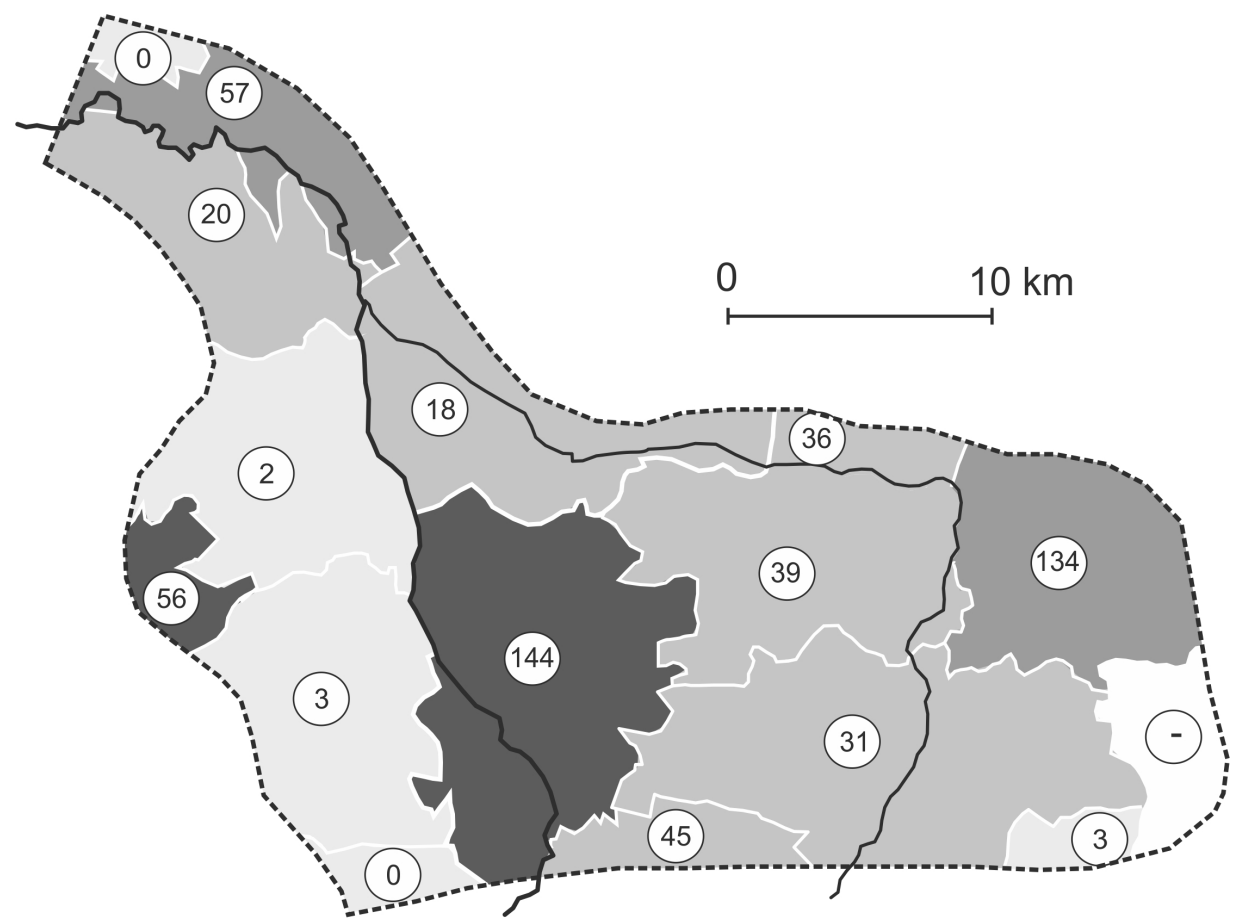

1. $x$

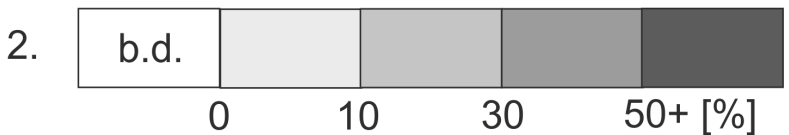

Ryc. 6. Udział gmin w łącznej liczbie punktów przyznanych dla powiatu w kategorii I „Potencjalne cele turystyki kulturowej" w waloryzacji metodą A. Mikos v. Rohrscheidt (2010)

1. liczba przyznanych punktów, 2. udział w łącznej liczbie punktów dla powiatu.

Participation of individual communes in the county's overall evaluation score in Category I "Potential goals of cultural tourism", using the A.Mikos v. Rohrscheidt valuation method (2010)

1. number of points awarded, 2. share in the total number of points for the county.

Źródło/Source: opracowanie własne na podstawie arkuszy waloryzacyjnych/own work besed on evaluation paper: A. Główczyńska (2009), J. Stefańska (2010), M. Gorączko i A. Gorączko (2016a, 2016b). 


\section{Podsumowanie}

Rozwój wiejskiej bazy turystycznej, jaki się dokonał na przestrzeni ponad dwóch ostatnich dekad w wielu rejonach Polski, nie objął jak dotąd swoim zasięgiem obszaru Kotliny Kolskiej. Prawdopodobnie główną tego przyczyną był fakt, że ten monofunkcyjny region z uwagi na niskie walory przyrodnicze i estetyczne (Bartkowski 1986) do niedawna nie był postrzegany jako atrakcyjny turystycznie (Bański 2016). Sytuacja ta uległa zmianie w wyniku przeobrażenia prowincjonalnego dotychczas miasteczka Uniejów w wyspecjalizowany ośrodek usług turystycznych o zasięgu ponadregionalnym, którego wiodące elementy stanowią kompleks basenów termalnych i nowo utworzone uzdrowisko (Gorczyczewska i Smętkiewicz 2013; Gorączko i Gorączko 2016b). Wygenerowano w ten sposób znaczny ruch turystyczny w środkowej części Kotliny Kolskiej, któremu sprzyja uzyskanie przez miasto bardzo dobrej dostępności komunikacyjnej (obecność autostrady A2) oraz jego centralne położenie w kraju. Drugim znaczącym pod względem turystycznym, choć mniej jak dotąd spopularyzowanym, ośrodkiem jest miasto Łęczyca, położone przy zachodniej granicy Kotliny Kolskiej. W obydwu przypadkach szczególnie ważną rolę w kreowaniu oferty turystycznej odegrało eksponowanie lokalnych walorów kulturowych. Jak wykazały badania autorów, podobnej strategii natomiast nie stosują w analizowanym terenie właściciele gospodarstw świadczących usługi turystyczne, nie tylko w odniesieniu do dalszej okolicy, ale nawet miejscowości, w której sami mieszkają. Niemniej, z uwagi na systematyczny wzrost liczby turystów w regionie, przewiduje się, że zapotrzebowanie na wiejskie obiekty rekreacyjno-wypoczynkowe w najbliższej przyszłości zwiększy się. Będzie to jednak proces odbywający się w obrębie Kotliny Kolskiej w sposób nierównomierny, dotyczący głównie obszarów o znacznym potencjale turystyczno-kulturowym, w przypadku których walory przyrodnicze mogą pełnić rolę drugorzędną. Już teraz 9 z 13 istniejących agroturystycznych i turystycznych gospodarstw wiejskich zlokalizowanych jest na terenie gminy Uniejów lub w gminach z nią sąsiadujących.

Autorzy składają podziękowania Recenzentom, których uwagi i sugestie w istotny sposób wpłynęły na ostateczną postać artykułu.

\section{Literatura}

Bank Danych Lokalnych (BDL), 2016, GUS, Warszawa.

Bański J., 2004, Możliwość rozwoju alternatywnych źródeł dochodu na obszarach Wiejskich, Studia Obszarów Wiejskich, 5, s. 9-22.

Bański J. (red.), 2010, Atlas Rolnictwa Polski, IGiPZ PAN, Warszawa.

Bański J. (red.), 2016, Atlas obszarów wiejskich w Polsce, IGiPZ PAN, Warszawa.

Bednarek-Szczepańska M., Bański J. 2014, Lokalizacyjne uwarunkowania oferty gospodarstw agroturystycznych w Polsce, Przegląd Geograficzny, 86, 2, s. 243-260

Bański J., Bednarek-Szczepańska M. 2016, The influence of landscape capital differentiation on the offer of agro-tourist facilities in Poland, [w:] Meeting Challenges for Rural Tourism through CoCreation of Sustainable Tourist Experiences, Cambridge Scholars Publishing, s. 223-241.

Bartkowski T., 1986, Zastosowanie geografii fizycznej, PWN, Warszawa.

Cabaj W., Kruczek Z. 2007, Podstawy geografii turystycznej, Proksenia, Kraków. 
Cichowska J., 2011, Znaczenie walorów przyrodniczych w rozwoju agroturystyki, Infrastruktura i Ekologia Terenów Wiejskich, 10, PAN Oddział w Krakowie, Komisja Technicznej Infrastruktury Wsi, s. 173-186.

Cichowska J., 2014, Analiza odległości gospodarstw agroturystycznych od miejsc istotnych dla turystów w województwie kujawsko-pomorskim, Infrastruktura i Ekologia Terenów Wiejskich, IV/2, PAN Oddział w Krakowie, Komisja Technicznej Infrastruktury Wsi, s. 1255-1270.

Cynarski W.J., Słopecki J., 2011, Treści turystyki kulturowej w obszarze badań agroturystyki i turystyki wiejskiej w świetle polskiej literatury przedmiotu, Turystyka Kulturowa, 10, s. 25-34

Dmochowska-Dudek K., Tobiasz-Lis P., Wójcik M., 2015, Funkcja turystyczna obszarów wiejskich woj. łódzkiego - uwarunkowania strukturalne i planistyczne, Studia KPZK PAN, 162, s. 199-216.

Duda-Seifert M. 2015, Kryteria oceny atrakcyjności turystycznej obiektów architektury w świetle literatury, Turystyka Kulturowa, 4, s. 74-87.

Durydiwka M., 2012, Czynniki rozwoju i zróżnicowanie funkcji turystycznej na obszarach wiejskich w Polsce, Uniwersytet Warszawski, Warszawa.

Główczyńska A., 2009, Waloryzacja turystyczno-kulturowa Miasta Koło i powiatu kolskiego, Turystyka Kulturowa, 1, s. 35-42.

Gorączko M., Gorączko A., 2012, W kopalni soli w Kłodawie, Format UTP, 3 (62)/4 (64), s. 68-69.

Gorączko M., Gorączko A., 2013, Cechy regionalne w budownictwie na terenie gminy Uniejów, Biuletyn Uniejowski., 2, s. 53-65.

Gorączko M., Gorączko A., 2015, Vernacular architecture and traditional rural landscape in new socio-economic realities - a case study from Central Poland, [w:] D.Szymańska, J.Biegańska (red), Bulletin of Geography. Socio-economic Series, 30, s. 43-57.

Gorączko M., Gorączko A., 2016a, Raport z analizy potencjału turystyczno-kulturowego Łęczycy i powiatu tęczyckiego, Turystyka Kulturowa, 5, s. 165-181.

Gorączko M., Gorączko A., 2016b, Raport z analizy potencjału turystyczno-kulturowego powiatu poddębickiego, Turystyka Kulturowa, 6, s. 125-145.

Gorączko M., Gorączko A. 2016c, Potencjalne znaczenie tradycyjnego budownictwa wiejskiego w rozwoju gminy Uniejów, [w:] K.Heffner, B.Klemens (red), Obszary wiejskie-wiejska przestrzeń i ludność, aktywność społeczna i przedsiębiorczość, Studia KPZK PAN, 167, s. 156-171.

Gorączko M., Sobczak-Piąstka J. 2016, Rewitalizacja mostu Baileya na rzece Ner w miejscowości Sobótka, Materiały Budowlane, 12, s. 82-83

Gorączko M., Gorączko A., 2017, Stan zachowania dworku Marii Konopnickiej w Gusinie w kontekście jego ewentualnej rewitalizacji, Biuletyn Uniejowski, UŁ, Łódź-Uniejów (w druku).

Gorczyczewska E., Smętkiewicz K., 2013, Budowa i promocja marki miejsca na przykładzie uzdrowiska termalnego Uniejów, Studia Ekonomiczne, 144, s. 395-408.

Janeczko E., Anderwald D., 2011, Birdwatching jako nowa forma turystyki na obszarach leśnych i przyrodniczo cennych w Polsce, Studia i Materiały CEPL w Rogowie, 13, 2 (27), s. 307-314.

Kałamucki K., 2003, Walory przyrodnicze czynnikiem stymulujqcym rozwój turystyki w województwie podkarpackim, [w:] R. Horodeński, C. Sadowska-Snarska (red.), Walory przyrodnicze jako czynnik rozwoju regionów wschodniej Polski, Wyższa Szkoła Ekonomiczna, Białystok, s. 285-286.

Kałowska J., Poczta-Wajda A., 2008, Walory naturalnego środowiska jako determinant rozwoju turystyki wiejskiej w Wielkopolsce, Wieś i Rolnictwo, 139, s. 115-128.

Kowalczyk A. 2001, Geografia turyzmu, PWN, Warszawa.

Kowalczyk A., Derek M. 2010, Zagospodarowanie turystyczne, PWN, Warszawa.

Kondracki J., 1998, Geografia regionalna Polski, PWN, Warszawa. 
Kordowska M., Kulczyk S., 2014, Stan i perspektywy rozwoju turystyki ornitologicznej w Polsce, Turyzm, 24/2, s.17-24.

Kozak M. W., 2006, Konkurencyjność turystyczna polskich regionów, Studia Regionalne i Lokalne, 3 (25), s. 49-65.

Kruczek Z., 2011, Atrakcje turystyczne. Fenomen, typologia, metody badań, Monografia, 10, Proksenia, Kraków.

Lityński M., 2007, Program rozwoju turystyki kajakowej na rzece Warcie, Wielkopolska Organizacja Turystyczna, Poznań.

Mikos von Rohrscheidt A., 2010, Turystyka kulturowa. Fenomen, potencjat, perspektywy, Kultour, Poznań.

Nowacki M. 2007, Metody i kierunki badań atrakcji turystycznych, Problemy Turystyki, 1-4, Warszawa, s. 59-72.

Orlikowski D., Szwed L., 2011, Zagospodarowanie terenów pogórniczych KWB „Adamów” SA w Turku - krajobraz przed rozpoczęciem działalności górniczej i po jej zakończeniu, Górnictwo i Geoinżynieria, 35, 3, s. 225-240.

Piotrowski J.P., Idziak W., 2004, Kultura bogactwem turystyki wiejskiej, Fundacja Wspomagania Wsi, Warszawa.

Poczta J. 2013, Wiejska turystyka kulturowa zgodna z paradygmatem zrównoważonego rozwoju, Turystyka Kulturowa, 4, s. 21-35.

Przezbórska-Skobiej L., 2014, Atrakcyjność turystyczna obszarów wiejskich a rozwój turystyki wiejskiej i agroturystyki, [w:] A. Niezgoda, G. Gołembski (red.), Turystyka wobec zmian współczesnego świata. Strategie, marketing, programowanie, Wydawnictwo Uniwersytetu Ekonomicznego w Poznaniu, Poznań, s. 118-131.

Przybyszewska-Gudelis R., Grabiszewski M.A., Iwicki S., 1979, Problematyka waloryzacji i zagospodarowania turystycznych miejscowości krajoznawczych w Polsce, IT, Warszawa.

Sołoma L., 2002, Metody i techniki badań socjologicznych. Wybrane zagadnienia, Wydawnictwo UWM, Olsztyn, s. 126-127.

Stefańska J., 2010, Waloryzacja turystyczno-kulturowa powiatu tureckiego, Turystyka Kulturowa, 12 , s. 38-43.

Stos D., Janusz T., 1986, Województwo konińskie. Monografia regionalna. Zarys dziejów, obraz współczesny, perspektywy rozwoju, Uniwersytet Łódzki, Urząd Wojewódzki w Koninie, Łódź-Konin.

Suliborski A., Kulawiak A., 2016, Niewykorzystany potencjał kultu religijnego miejscowości wiejskiej. Przykład Świnic Warckich w województwie łódzkim, Studia Obszarów Wiejskich, 44, s.109-124.

Ziernicka-Wojtaszek A., Zawora T., 2011, Wybrane metody oceny atrakcyjności agroturystycznej terenów wiejskich, Infrastruktura i Ekologia Terenów Wiejskich, 2, s. 235-245.

\section{Summary}

The development of the tourist infrastructure in the rural area of Koło Basin has not yet progressed beyond its initial phases. An evidence of that is the still underdeveloped lodging base existing in region. One of the root causes of this situation is the low attractiveness of the landscape of the basin. The potential for activation of the tourism industry in the region lies therefore in exploiting the local cultural resources, which - according to research - are significant in the area concerned. Additionally, Koło Basin does not provide 
conditions suitable for large-area or factory farming, and therefore the region has maintained the landscape defined by smallholding farms attractive to tourists searching for genuine atmosphere of the traditional Polish countryside. One of the cultural assets of the region worth mentioning is the well-preserved traditional rural architecture, erected using the local deposits of limestone- a unique appearance of that kind of structures on the Polish lowlands. However, the tourism operators in the region rarely refer in their offers to its cultural specificity, emphasizing the common attractions, which tend to be presented in an inflated manner, beyond their actual standard. 
http://rcin.org.pl 